\title{
The multi-component structuration of the species diversity of groundfish assemblages of the east coast of Corsica (Mediterranean Sea): Variation according to the bathymetric strata
}

\author{
Bastien Mérigot ${ }^{\mathrm{a}, \star}$, Jacques A. Bertrand ${ }^{\mathrm{b}}$, Jean-Claude Gaertner $^{\mathrm{a}}$, Jean-Pierre Durbec ${ }^{\mathrm{a}}$, \\ Nabila Mazounic, Claude Mantéa .
}

\author{
${ }^{a}$ Centre d'Océanologie de Marseille, LMGEM, UMR CNRS 6117, Université de la Méditerranée, Campus de \\ Luminy, 13009 Marseille, France \\ ${ }^{\mathrm{b}}$ IFREMER, Département Ecologie et modèles pour l'halieutique, Rue de l'lle d'Yeu, BP 21105, 44311 Nantes \\ cedex 03, France \\ ${ }^{c}$ CEPRALMAR, Stratégie Concept Bât. 1, 1300 Avenue A. Einstein, 34000 Montpellier, France
}

\author{
*: Corresponding author : Tel.: 33. (0) 4.91.82.91.38; fax: 33. (0) 4.91.82.96.41. \\ E-mail address: bastien.merigot@univmed.fr (B. Mérigot).
}

\begin{abstract}
:
The multi-component aspect of species diversity of groundfish assemblages was examined on the basis of a set of experimental trawl surveys conducted on the east coast of Corsica. We analysed and compared the structuration of diversity within three different bathymetric strata: the continental shelf (60 - $120 \mathrm{~m}$ depth), the upper slope $(250-400 \mathrm{~m})$ and the lower slope $(450-570 \mathrm{~m})$. For each of these three bathymetric strata, we simultaneously analysed 12 indices that are theoretically complementary and relate to 4 diversity components: (1) the number of species, (2) rarity, (3) evenness and (4) taxonomic diversity. Principal component analysis based on Spearman's correlation coefficients was carried out to investigate empirical relationships between the selected indices. Our results showed not only that a single diversity index cannot provide a complete view of the groundfish diversity along the east coast of Corsica, but also that - in some cases - one index cannot even encapsulate a complete description of a specific diversity component. We also found that the nature and the number of independent diversity components slightly varied from one bathymetric stratum to another. The main differences - which mainly occurred in the deepest bathymetric stratum - might be associated with lower density of individuals and lower dominance of some species at deeper depths. Finally, this study is the first dealing with groundfish diversity in this area, which is currently characterized by one of the lowest fishing intensity rates in the northern Mediterranean Sea. It might be considered as a first "reference state" with a view to monitoring the spatio-temporal changes in species diversity patterns along the east coast of Corsica in the future.
\end{abstract}

Keywords: demersal fish; diversity indices; bathymetry; taxonomic relatedness; Corsica; Mediterranean Sea 


\section{Introduction}

Interest in biological diversity has recently increased in response to the damage caused to ecosystems by anthropic activities. However, despite the growing awareness that species diversity is a complex concept which requires measures that take into account several aspects of diversity (Purvis and Hector, 2000; Magurran, 2004), most marine field studies are still focusing on a single or - at best - a very limited number of diversity components (mainly species richness and evenness). In addition, despite the fact that each diversity component could be analysed through various indices which differ with regard to their theoretical properties (Peet, 1974; Gaston, 1994; Beisel et al., 2003; Clarke and Warwick, 1998, 2001), empirical relationships between indices within and between components have been very little studied. To our knowledge, field studies comparing the properties of indices within a single diversity component have exclusively focused on species evenness (Ricotta et al, 2001; Beisel et al., 2003). Moreover, the few studies that have proposed the simultaneous analysis of several diversity components did not consider the taxonomic relatedness between species (Beisel et al., 1998; Wilsey et al., 2005) with the exception of a recent study (Mérigot et al., 2007).

The number of dimensions to describe variation in diversity may depend on underlying environmental gradients to which each diversity index responds (Wilsey et al., 2005). These authors suggested that future studies should investigate how environmental gradients affect the strength and form of the association among diversity components. For conservation purposes, the analysis and the comparison of the structuration of species diversity in different environmental situations is of particular interest with a view to monitoring and managing species diversity within the frame of integrated management (Mazouni, 2006). Such studies have not yet been undertaken even for factors known to play a dominant role in determining the structuration of the species composition of groundfish assemblages, such as the bathymetry (Bianchi, 1992; Fujita et al., 1995; Moranta et al., 1998; Ungaro et al., 1999; Gaertner et al., 2002; Magnussen, 2002). 
In the Mediterranean Sea, the few studies dedicated to Mediterranean groundfish diversity have mainly focused a very few components such as species richness and evenness (Blanchard, 2001; Labropoulou and Papaconstantinou, 2004; Colloca et al., 2003; Gaertner et al., 2005a). The work of Gristina et al. (2006) is the only one to consider taxonomic diversity in the analyses dedicated to fishing pressure on groundfish assemblages in the Strait of Sicily. This general lack of knowledge is particularly striking for the east coast of Corsica. To date, only one study has offered an initial quantified picture of groundfish diversity in this area but it was restricted to analysis of the species richness component (Gaertner et al., 2007). Because it is among the least intensively fished areas in the whole of the northern Mediterranean Sea (Relini et al., 1999), improving our knowledge of patterns of groundfish diversity is particularly important in this region. Such findings could be considered as a reference base with regard to the northern Mediterranean Sea with a view to monitoring the influence of fisheries on diversity in the future. This is particularly a striking point in the context of the European Marine Strategy where fish will be used to define the status of marine eco-region.

In this context, we analysed data recently collected during the MEDITS project (Mediterranean International Trawl Survey; Bertrand et al., 2002a) which provide a first opportunity to analyse the multi-component aspect of species diversity of groundfish assemblages in this region. We have investigated species diversity of the groundfish assemblages through the simultaneous analysis of four of its main components (species richness, evenness, rarity and taxonomic diversity) in three bathymetric strata. The questions addressed in this study are:

i) What are the components of diversity which provide a complementary view of the species diversity of groundfish assemblages? Are there some redundant indices between and within the different components?

ii) Does the multi-component structure of species diversity vary according to bathymetric strata? 


\section{Materials and methods}

\subsection{Study area and sampling design}

We analysed data collected from five annual bottom trawl surveys performed over the continental shelf and along the slope off the east coast of Corsica within the framework of the MEDITS project (Bertrand et al. 2002a, Fig. 1). Each of these surveys was carried out at the same period of the year (May-June) in 1995 (14 tows) 1996 (18 tows), 1998 (15 tows), 1999 (17 tows) and 2000 (15 tows). The 1997 survey has been excluded in view of the low number of hauls carried out this year due to technical impediments. The sampling procedures for these surveys were standardised according to a common protocol including the use of the same gear and the same sampling strategy for the whole study period (Anon., 1998). A stratified random-sampling design was used, based on bathymetry. Fig. 1 here

The standard gear was a bottom trawl net (GOC 73, Fiorentini et al., 1999) with $20 \mathrm{~mm}$ cod-end mesh size (stretched mesh). Hauls were performed during daylight hours and their standard duration was $30 \mathrm{~min}$ on the continental shelf and $60 \mathrm{~min}$ below. The vertical opening of the gear was about 2 $\mathrm{m}$, and its wing spread about $18 \mathrm{~m}$ (Bertrand et al., 2002b). Information recorded by an underwater Scanmar system to monitor the trawl geometry (horizontal and vertical openings, contact with the bottom) allowed us to select out the tows that were not properly carried out. During the surveys, all the fish caught were identified at species level and counted.

\subsection{Data analysis}

We analysed groundfish diversity separately on the basis of three bathymetric strata: the continental shelf (ranging from 60 to $120 \mathrm{~m} ; 38$ tows), the upper slope (ranging from 250 to $400 \mathrm{~m}$; 18 tows) and the lower slope (ranging from 450 to $570 \mathrm{~m}$; 23 tows). These stratum boundaries were slightly reduced in comparison with the ones originally defined during the Medits protocol due to (1) the lack of samples close to original boundaries and (2) the fact that we ruled out trawls showing too many differences in the trawled area (see tests hereafter). Otherwise, each of these three strata were characterized by a specific species composition in groundfishes (Gaertner et al., 2005b). For each of 
these three bathymetric strata we investigated the diversity patterns of demersal fish assemblages through the analysis of four major components: (1) number of species, (2) rarity, (3) evenness and (4) species taxonomy.

\section{Number of species}

The number of species is still the most widely used component for describing diversity in both marine and terrestrial ecosystems (Rosenzweig, 1995; Gaston and Spicer, 1998). Estimates of species richness are highly sensitive to sampling effort (Gaston and Spicer, 1998). Thus, only the tows with close swept areas have been included in the analyses (i.e. 38 tows for the continental shelf, 18 and 23 tows for the upper and the lower slope respectively). For present purposes, we have excluded the tows with a sweep area outside the range $0.04-0.06 \mathrm{~km}^{2}$ for the continental shelf, and $0.08-0.13 \mathrm{~km}^{2}$ for the upper and lower slopes. A Chi ${ }^{2}$ test of independence in the three cases (Chi2 $=9.73, \mathrm{df}=9, \mathrm{p}=0.37 ;$ Chi2 $=11.87, \mathrm{df}=9, \mathrm{p}=0.22$ and Chi2 $=12.16$, df $=9, \mathrm{p}=0.20$ respectively) showed no effect of the swept area variation on the number of species collected among the selected tows in each of the three bathymetric strata. This test has been computed on a contingency table crossing four classes for each variable delimited by mean of quantile values. This leads to consider (4-1) $\mathrm{x}(4-1)=9$ degrees of freedom in the computation of the test. Thus, we can consider the number of species per haul as a measure of species density $S$ (Table 1 ). In addition, we also computed Margalef's species richness index $D_{\mathrm{mg}}$ (Table 1); this index adjusts the number of species according to the total number of individuals sampled in each haul. We chose Margalef's species richness index for its ease of calculation and its widespread use (Magurran, 2004).

\section{Rarity}

We took into account rarity which is a component extensively used in conservation strategy. This concept is usually defined on the basis of the level of species local abundance or the species range size (occurrence), but whatever the approach used, definitions of rarity are necessarily arbitrary (Gaston, 1994). Manté et al. (2003) proposed several statistical methods for deciding whether or not 
a species is rare, according to its abundance in a series of surveys. These methods depend on a "rarity parameter", which should be determined from replicated data. Unfortunately, we did not have replicated tows at our disposal. Furthermore, because species with a restricted occurrence are usually the most vulnerable to environmental change (Thomas and Mallorie, 1985), the occurrence criterion has been the most widely used for conservation purposes. Moreover, in the present work, the high noise associated with trawl surveys limited our ability to estimate the absolute number of individuals for each species with precision. The definition of rare species according to a pre-defined threshold based on low local abundance would be particularly sensitive to this problem. Thus, in our study we used the criterion of occurrence rather than local abundance to define rarity (Table 1). Hereafter, rare species are those that occurred in less than $5 \%$ of the tows in each bathymetric stratum. For the continental shelf, 18 species, including 4 Chondrichthyes, were below this threshold (Appendix 1). Respectively for the upper and the lower slope, 16 and 19 species, including 4 and 2 Chondrichthyes, occurred in less than $5 \%$ of the tows and thus considered as rare species in our work.

\section{Evenness}

Because evenness estimates may be mainly related to rare or dominant species according to the index used (Smith and Wilson, 1996; Ricotta et al., 2001; Beisel et al., 2003), we considered two indices of evenness (Table 1). First, we used the Heip's evenness index $E_{\text {Heip }}$ (Heip, 1974) which is assumed to be mainly sensitive to variation in rare species (Beisel et al., 2003). Secondly, we used the $d$ Berger Parker index (Berger and Parker, 1970) which is acknowledged to be only sensitive to variations in the most dominant species (May, 1975; Magurran, 2004). We computed 1/d (rather than $d$ ) which increases when abundances are evenly distributed (maximum diversity) among the species and decreases with dominance (low diversity).

We also computed heterogeneous indices, which combine both the number of species and evenness components in a single value (Table 1): the Shannon-Wiener index $H^{\prime}$ (Shannon and 
Weaver, 1949) and the Simpson concentration $D$ (Simpson, 1949). $H^{\prime}$ is assumed to be sensitive to the changes in abundance of rare species while $D$ is heavily weighted towards the dominant species and less sensitive to species richness than $H^{\prime}$ (Peet, 1974; Boyle et al., 1990). Although they are not focused on a single diversity component, we used these two very popular heterogeneous indices to facilitate comparisons of our results with previous works and to better understand their properties in comparison with indices dedicated to a single diversity component. We used Simpson diversity (1$D)$ - rather than $D$ - because it is positively correlated with diversity.

\section{Species taxonomy}

All the indices mentioned above assume that each species contributes to diversity in the same manner and they do not explicitly take into account functional differences between species. In ecology, most often, analyses of taxonomic diversity have been carried out as a first - and rough step towards assessing some aspects of the functional diversity (von Euler and Svensson, 2001). It has even been postulated that taxonomic and functional structure could be related (Warwick and Clarke, 1998; von Euler and Svensson, 2001; Ramos-Miranda et al., 2005) and that the taxonomic range of an assemblage could be important in maintaining ecosystem stability during natural or anthropogenic disturbances (Tilman, 1996).

Consequently, we computed five taxonomic indices proposed by Warwick and Clarke (1995) and Clarke and Warwick $(1998,2001)$ (Table 1) that quantify the taxonomic diversity of a faunal assemblage in terms of average distance of all pairs of individuals (or species) in a sample by tracing their distances through the Linnaean taxonomic tree. Each of these five indices has specific properties. Taxonomic diversity $\Delta$ is the average distance (path length) traced through the taxonomic tree between every pair of individuals in a sample, including the individuals which belong to the same species whereas taxonomic distinctness $\Delta^{*}$ considers individuals which only belong to different species (Warwick and Clarke, 1995). $\Delta$ can be seen as a generalization of the Simpson diversity index incorporating an element of taxonomic relatedness but it differs from $\Delta^{*}$ in its sensitivity to species dominance (Table 1, Clarke and Warwick, 1998). $\Delta^{*}$ is modified to remove 
some of the dependence of $\Delta$ on the species abundance distribution represented by the $x_{i} . \Delta$ is divided by its value when the hierarchical classification collapses to the special case of all species belonging to a single genus, removing the evenness component from $\Delta$. The resulting ratio $\Delta^{*}$, being literally $\Delta$ divided by Simpson diversity, is then more nearly a function of pure taxonomic relatedness of individuals (Clarke and Warwick, 1998).

Because collecting presence-absence data can be easier and less time consuming than abundance data, we also investigated a third index $\Delta^{+}$(Table 1) in order to study the possible "loss of information" with the previous taxonomic index that requires abundance data. Average taxonomic distinctness $\Delta^{+}$can be viewed as the average distance traced through the taxonomic tree between each pair of species in the sample (Clarke and Warwick, 1998).

In addition, we applied the index of variation in taxonomic distinctness $\Lambda^{+}$which is based on the evenness of the taxonomic level distribution in the taxonomic tree, being mathematically the variance of $\Delta^{+}$(Table 1). This index is a measure of the taxonomic tree asymmetry. It is supposed to provide additional information to that of the three others (Clarke and Warwick, 2001). Finally, Total Taxonomic Distinctness $s \Delta^{+}$(Table 1) was proposed by Clarke and Warwick (2001) as a useful measure of total taxonomic breadth of an assemblage, as a modification of species richness including taxonomic information.

There are two main methods to define $\omega_{i j}$ the weight given to the path length linking species $i$ and $j$ in the taxonomic tree (Clarke and Warwick, 1999), but Rogers et al. (1999) showed that the values $\Delta^{+}$calculated with or without $\omega_{i j}$ modified to reflect the quantitative reduction in taxon richness were strongly correlated. Thus, we have adopted the simplest form of $\omega_{i j}$ with equal step-lengths between two successive taxonomic levels, setting the $\omega_{i j}$ at 100 for two species connected at the highest (taxonomically coarsest) possible level (Clarke and Warwick, 1999). We have used six taxonomic levels (Appendix 1), so that $\omega_{i j}=16.7$ (i.e. species in the same genus), 33.3 (i.e. same family but different genera), 50 (i.e. same order but different families), 66.7 (i.e. same class but different orders), 83.3 (i.e. same phylum but different classes) and 100 (i.e. different phyla), 
respectively. Taxonomic indices have been computed using the PRIMER software (Clarke and Gorley, 2001).

Table 1 here

Comparison between the indices for the five years was carried out using a non-parametric ANOVA (Kruskal-Wallis test) in order to study year effects. In all cases, indices did not present any significant year effect $(\mathrm{p}>0.05)$, except for $1 / d$ on the upper slope $(\mathrm{p}=0.04)$ and $\Delta^{+}$on the lower slope $(p=0.03)$ for which the effect was weak. Year effect was then considered as negligible.

Data were adjusted for depth influence within each of the three bathymetric strata by means of a non-parametric local regression (Loess). A regression on each diversity index has been investigated for the effect of depth separately within each of the three bathymetric strata. This enabled us to compute residuals for each diversity index within each of the three bathymetric strata and to provide a quantity free of depth effect within the bathymetric stratum. Loess residuals have then been used in the analyses dedicated to the relationships among diversity components, i.e principal component analyses, to avoid depth effect within each bathymetric stratum. This enabled us to study more purely the multi-component structuration of species diversity in each of the three strata and then to compare the structuration of diversity between each bathymetric stratum. We have to keep in mind that we aim to compare variations in the relationships between species diversity indices (and components) from one bathymetric stratum to another but not to compare variations in diversity values. Furthermore, differences in sampling effort between the continental shelf and the slope prevented us from making comparisons from the values of the majority of indices that are sensitive to differences in sampling effort (Magurran, 2004).

Empirical relationships among diversity components and their respective indices were investigated by means of principal component analyses (PCA). This procedure was performed to identify both redundant and complementary indices of diversity in our data set. Because atypical values of some indices could modify correlation coefficients based on abundance data, we carried out a PCA based 
on the ranked indices values (Joliffe, 1986). This method allows calculation of eigenvalues and eigenvectors of the Spearman's rank correlation matrix. The projection of diversity indices onto the factorial axes of the PCA provides a graphic overall perception of the correlations between indices. However, it does not represent the exact reality of these correlations, but only a less distorted description of them. Hence, the Spearman's correlations matrix was analysed in complement. It provided less directly accessible but more precise information on the correlations between the indices studied. Principal-components analyses were conducted separately for each of the three strata. All statistical analyses were performed using R software (Ihaka and Gentleman, 1996).

\section{Results}

\subsection{Characterisation of the species assemblages in each bathymetric stratum}

Representatives of 73, 58 and 64 groundfish species were identified in the 38, 18 and 23 samples analysed respectively from the continental shelf, the upper and the lower slope (Table 2, Appendix 1). The number of individuals caught by $\mathrm{Km}^{2}$ varied considerably between the three bathymetric strata, from 119345 individuals caught by $\mathrm{Km}^{2}$ on the continental shelf to 41044 on the upper slope, and 2917 on the lower slope (Table 2).

Table 2 here

The most dominant species caught over the continental shelf (Spicara smaris) represented $77.47 \%$ of the total abundance (Table 3), while over the upper and the lower slope this species was different and represented less dominance (respectively $35.37 \%$ for Gadiculus argenteus argenteus and 20.92 $\%$ for Galeus melastomus). The cumulative percentage of the 10 most abundant species was quite consistent throughout the three bathymetric strata: $94.93 \%, 92.95 \%$ and $88.01 \%$ respectively (Table 3). Mean values for each species diversity index are reported (Table 2) to provide a first reference state with a view to monitoring changes in species diversity in the study area in the future. Table 3 here 


\subsection{Empirical relationships among species diversity components}

The projection of diversity indices onto the correlation circle of the PCA made it possible to display different groups of indices (Fig. 2). For the continental shelf, the two principal components accounted for $68 \%$ of the total inertia. The first principal component (49.7\%, Fig. 2a) was highly correlated with one index of the number of species $\left(D_{\mathrm{mg}}\right)$, all evenness indices $\left(E_{\text {Heip }}\right.$ and $\left.1 / d\right)$, the two heterogeneous indices $\left(H^{\prime}\right.$ and $\left.1-D\right)$ and with one of the taxonomic diversity indices $(\Delta)$. In contrast, two of the indices focused on the number of species, $S$ and $s \Delta^{+}$were weakly correlated with all the other indices (see Fig. 2a; Table 4a). The projection of the three other taxonomic indices $\left(\Delta^{*}, \Delta^{+}\right.$, and $\left.\Lambda^{+}\right)$and Rarity clearly showed that they did not contribute to the first two principal components. The weak Spearman's correlations observed between these indices (Table 4a) confirmed that each of them tend to provide complementary information on groundfish species diversity on the continental shelf of the east coast of Corsica. In short, the simultaneous analysis of PCA and Spearman correlation coefficients provides a basis for roughly grouping the 12 species diversity indices studied into 6 complementary components of diversity on the continental shelf: (1) species density $S$ and $s \Delta^{+}$, (2) evenness $\left(E_{\text {Heip }}, 1 / d, H^{\prime}, 1-D, \Delta\right)$ and $D_{\mathrm{mg}}$, (3) rarity and each of the three other measures of taxonomy: (4) $\Delta^{*},(5) \Delta^{+}$, and (6) $\Lambda^{+}$.

Fig. 2, Table 4 here

For the upper slope, the two principal components accounted for $68.2 \%$ of the total inertia (Fig. 2b). The clustering of diversity indices into groups was relatively similar to those observed for the continental shelf (Fig. 2b, Table 4b). The main exception concerned $D_{\mathrm{mg}}$. Whereas it was less obvious from the analysis of the first factorial plan, the Spearman correlation coefficients showed that $D_{\text {mg }}$ was mainly correlated with $S$ and $s \Delta^{+}$(Table 4b). Finally, for the lower slope, two principal components accounted for $66.8 \%$ of the total inertia (Fig. 2c). The relationships observed between indices showed little variations in comparison to the upper slope. However, the evenness group $\left(H^{\prime}\right.$, $1-D, 1 / d, E_{\text {Heip }}$ and $\Delta$ ) appeared to be more heterogeneous (Fig. 2c), with correlations between indices that are lower than for those observed on the upper slope (Table 4c). In short, we found an overall reproducibility of the relationships between diversity indices and components across the 
bathymetric strata which is however accompanied by a limited number of variations (Fig. 2, Table 4).

\section{Discussion}

\subsection{The multi-component structuration of groundfish diversity}

For the continental shelf, the upper and the lower slope, we found that the whole set of diversity indices considered in our study might be split into several distinct and complementary groups of indices of groundfish diversity. This result strongly supports the conclusions of recent theoretical works postulating that species diversity is a multi-component concept (Purvis and Hector, 2000), as empirically demonstrated recently (Wilsey et al., 2005; Mérigot et al., 2007). While our study dealt with four theoretical components of biodiversity, for each bathymetric stratum we have roughly clustered the twelve indices studied in more than four complementary diversity components. As a consequence, our results show not only that a single diversity index cannot provide a complete description of species diversity, but also that - in some cases - one index cannot even encapsulate a complete description of a specific diversity component. We found that this result is roughly reproducible in each the three bathymetric strata studied in Corsica. It is also similar to those previously found in another region for groundfish assemblages in the Gulf of Lions (Mérigot et al., 2007). Nevertheless, other studies are required in order to assess more precisely the scope of our results.

Otherwise, it is worth noting that catchability is species-dependent and consequently might affect our perception of species composition and diversity of the assemblages. Hence, this problem could lead to bias in the between-strata comparison of abundance-based diversity indices. Unfortunately, there is no perfect way to deal with this problem. However, it might be taken into account mostly if the population that is not caught by the trawl (small size individuals, etc.) strongly vary between strata, notably in their size distributions. In our case study, the use of the same gear in each bathymetric stratum limited any skew regarding the comparison in the relationships between diversity indices between bathymetric strata. 
Another striking point is that some indices which were described as complementary in theoretical works, appeared to be redundant in our field study. For instance, while evenness is considered as a multi-component concept (Smith and Wilson, 1996), our results showed that indices sensitive to changes in evenness of rare and dominant species were highly correlated in most of the studied areas (Table 4). Hence, their complementary properties were not verified. We also found a strong correlation between all the indices partly (i.e. Shannon and Simpson) or entirely (i.e. Berger-Parker and Heip) dedicated to the evenness component. In such a situation the use of Berger-Parker which is simple to understand and easy to measure (the identity of species other than the most abundant species does not need to be determined) might be a good candidate for summarizing in a single value the evenness component of diversity.

Moreover, the taxonomic diversity $\Delta$ is intended to take into account taxonomic relationships between individuals and is thus assumed to provide additional information to classical species diversity indices. However, considering both the continental shelf and the upper slope, we found a high correlation between $\Delta$ and the different indices based on abundance data (i.e. evenness and heterogeneous indices) with the exception of $\Delta^{*}$. This result suggests that $\Delta$ could be strongly dependent on the species abundance distribution but could fail to take into account the taxonomic component of groundfish diversity.

Finally, Total taxonomic distinctness $s \Delta^{+}$did not provide additional information on species richness on the continental shelf and the slope, which could make it relatively redundant as an index. Clarke and Warwick (2001) did not recommend the general use of $s \Delta^{+}$, which is dependant of the number of species, but it might be only useful for studies in which sampling effort is similar. In contrast, our results suggested that even in this situation $s \Delta^{+}$did not seem to provide additional information to species richness. In short, with the exception of $\Delta$ and $s \Delta^{+}$, our results agreed with Clarke and Warwick $(1998,2001)$ who stated that all the taxonomic indices appeared to provide additional and complementary information on diversity. More detailed discussions about the difference between 
expected complementary properties of indices and empirical relationships are available in Mérigot et al. (2007).

\subsection{Bathymetric effect on the multi-component feature of groundfish diversity}

Our results revealed that the number and the composition of the complementary groups of diversity indices were globally reproducible across the bathymetric stratum. This finding suggests that bathymetry has a low influence on the multi-component structuration of species diversity. For conservation purposes, this result is of particular interest with a view to monitoring and managing species diversity with a limited set of indices for the whole study area.

The overall reproducibility of the relationships between diversity indices and components across bathymetric strata were accompanied by a limited number of variations which mainly concerned some indices based on abundance data (evenness group and $D_{m g}$; see Fig. 2, Table 4). Possible explanations could be linked to differences in the faunistic characteristics between the three strata, i.e changes in dominance of species and in density of individuals. Firstly, the higher heterogeneity of the evenness group on the lower slope might be explained by a lower level of dominance in this stratum. We observed a decrease of the dominance between the bathymetric strata (Table 3). On the continental shelf, the most abundant species, Spicara smaris, represented $77.47 \%$ of the total abundance while on the lower slope the dominant species, Galeus melastomus represented only $20.92 \%$. Deep-water fish assemblages appeared to be more balanced and less dominated by a single species than shelf assemblages (Table 3). Such differences between the three systems in the underlying species abundance distribution might affect the relationships between indices based on abundance and explain the variations that we observed.

Secondly, we observed a higher correlation between $D_{m g}$, which adjusts the number of species by the number of individuals caught, and the component of the number of species in the deeper bathymetric strata, especially in the lower slope (see Fig. 2, Table 4). This might be explained by a lower density of individuals in these strata (Table 2). Indeed, the number of individuals caught 
seems to drastically decrease along the bathymetric gradient (Table 2), revealing a lower density in the deeper waters. This different density pattern might be linked to the specific conditions occurring in deeper waters, such as high water pressure, unpredictable arrival of energy inputs, long-term starvation which have been suggested as being responsible for the decrease of faunal abundance with increasing water depth (Thurston et al., 1994; Stora et al., 1999; Gooday et al., 2001; Cartes et al., 2002; Gutzmann et al., 2004).

In conclusion, our results clearly show that a single diversity index cannot provide a complete view of the groundfish species diversity. Otherwise, most of the relationships between diversity indices and components appeared to be reproducible between the different bathymetric strata. This result, which needs to be confirmed in other regions and on the basis of other environmental factors, might be very useful for choosing a limited set of complementary indices in the monitoring of species diversity in the future. More generally, the proposed approach might offer an easy and reproducible basis for defining what are the complementary components required to describe diversity in any case. In this respect, it is clearly a step towards the approach recommended by Purvis and Hector (2000) who stated that "The stronger the correlations [between diversity indices], the more reasonable it will be to reduce multiple measures to a few principal components, to create dimensions of diversity". Finally, our analysis gives the first quantitative outline of species diversity of groundfish assemblages along the east coast of Corsica, an area with one of the lowest rates of fishing pressure in the northern Mediterranean Sea (Relini et al., 1999). These findings might be considered as a "reference state" with a view to monitoring the spatio-temporal changes in species diversity patterns in this area in the future. The comparison of our results with those of similar studies carried out in more intensively fished areas - notably within the standardized framework of the MEDITS programme - could provide a basis for achieving a better understanding of the impact of fishing pressure on Mediterranean groundfish assemblage diversity. 


\section{Acknowledgements}

This study was carried out within the framework of the French part of the International MEDITS programme. We wish to thank all participants in the surveys conducted by the fishery laboratory of Ifremer-Sète. Financial support for B. Mérigot's PhD research came from the French Ministry of Research and Education. The manuscript was improved by the comments of two anonymous reviewers. We also thank M. Paul for correcting the English.

Appendix 1: Linnaean hierarchical classification of the species recorded in the study area ( ${ }^{\mathrm{a}}$ continental shelf, ${ }^{\mathrm{b}}$ upper slope, ${ }^{\mathrm{c}}$ lower slope). This matrix has been used to compute the taxonomic indices (see Table 1). * Rare species (i.e. occurrence $<5 \%$ ). All the species belong to the Chordata phylum.

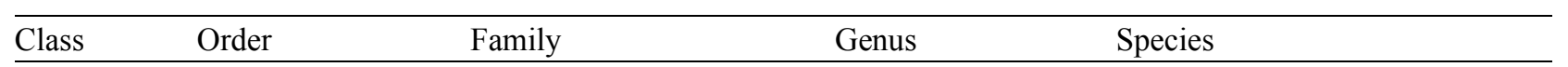

\begin{tabular}{|c|c|c|c|c|}
\hline Osteichthyes & Anguilliforme & Congridae & Conger & $\underline{\text { Conger conger }} \mathrm{b}^{*}, \mathrm{c}$ \\
\hline & & Nettastomatidae & Nettastoma & $\underline{\text { Nettastoma melanurum }}^{c^{*}}$ \\
\hline & Aulopiforme & Aulopidae & $\underline{\text { Aulopus }}$ & $\underline{\text { Aulopus filamentosus }}^{\mathrm{a}^{*}}$ \\
\hline & & Chlorophthalmidae & $\underline{\text { Chlorophthalmus }}$ & $\underline{\text { Chlorophthalmus agassizi }}^{{ }^{*, b, c}}$ \\
\hline & & Paralepididae & $\underline{\text { Paralepis }}$ & $\underline{\text { Paralepis speciosa }}^{\mathrm{c}^{*}}$ \\
\hline & Beryciforme & Trachichthyidae & Hoplostethus & Hoplostethus mediterraneus \\
\hline & & & & $\underline{\text { mediterraneus }}^{\mathrm{b}^{*}, \mathrm{c}}$ \\
\hline & Clupeiforme & Engraulidae & $\underline{\text { Engraulis }}$ & Engraulis encrasicolus $^{a}$ \\
\hline & & Clupeidae & $\underline{\text { Sardina }}$ & $\underline{\text { Sardina pilchardus }}^{\text {a }}$ \\
\hline & Gadiforme & Gadidae & $\underline{\text { Gadiculus }}$ & $\underline{\text { Gadiculus argenteus argenteus }}^{\mathrm{b}, \mathrm{c}}$ \\
\hline & & & $\underline{\text { Micromesistius }}$ & $\underline{\text { Micromesistius poutassou }}^{\mathrm{b}, \mathrm{c}}$ \\
\hline & & & Trisopterus & $\underline{\text { Trisopterus minutus }}^{\mathrm{b}^{*}}$ \\
\hline & & Lotidae & Gaidropsarus & $\underline{\text { Gaidropsarus biscayensis }}^{\mathrm{c}^{*}}$ \\
\hline & & & $\underline{\text { Molva }}$ & $\underline{\text { Molva dypterygia }}^{\mathrm{b}, \mathrm{c}}$ \\
\hline & & Macrouridae & $\underline{\text { Caelorinchus }}$ & $\underline{\text { Caelorinchus caelorhincus }}^{\mathrm{b}, \mathrm{c}}$ \\
\hline & & & Hymenocephalus & $\underline{\text { Hymenocephalus italicus }}^{\mathrm{b}, \mathrm{c}}$ \\
\hline & & & Nezumia & $\underline{\text { Nezumia sclerorhynchus }}^{c}$ \\
\hline
\end{tabular}




\begin{tabular}{|c|c|c|c|}
\hline & & $\underline{\text { Trachyrincus }}$ & $\underline{\text { Trachyrincus scabrus }}^{\mathrm{c}}$ \\
\hline & Merlucciidae & $\underline{\text { Merluccius }}$ & $\underline{\text { Merluccius merluccius }}^{\mathrm{a}, \mathrm{b}, \mathrm{c}}$ \\
\hline & Moridae & $\underline{\text { Gadella }}$ & Gadella maraldi $^{\mathrm{c}^{*}}$ \\
\hline & & $\underline{\text { Physiculus }}$ & Physiculus dalwigki $^{\mathrm{c}^{*}}$ \\
\hline & Phycidae & $\underline{\text { Phycis }}$ & $\underline{\text { Phycis blennoides }}^{\mathrm{b}, \mathrm{c}}$ \\
\hline Lophiiforme & Lophiidae & $\underline{\text { Lophius }}$ & $\underline{\text { Lophius budegassa }}{ }^{\mathrm{a}, \mathrm{b}}$ \\
\hline & & & $\underline{\text { Lophius piscatorius }}^{\mathrm{a}, \mathrm{b}, \mathrm{c}}$ \\
\hline Myctophiforme & Myctophidae & Benthosema & $\underline{\text { Benthosema glaciale }}^{\mathrm{c}^{*}}$ \\
\hline & & $\underline{\text { Ceratoscopelus }}$ & $\underline{\text { Ceratoscopelus maderensis }}{ }^{c}$ \\
\hline & & Diaphus & Diaphus holti $^{b^{*}, \mathrm{c}}$ \\
\hline & & Hygophum & $\underline{\text { Hygophum benoiti }}{ }^{*}$ \\
\hline & & & $\underline{\text { Hygophum hygomii }}^{\mathrm{c}}$ \\
\hline & & Lampanyctus & $\underline{\text { Lampanyctus crocodilus }}^{c}$ \\
\hline & & Myctophum & $\underline{\text { Myctophum punctatum }}^{\mathrm{c}}$ \\
\hline & & $\underline{\text { Notoscopelus }}$ & $\underline{\text { Notoscopelus bolini }}^{\mathrm{c}^{*}}$ \\
\hline & & & $\underline{\text { Notoscopelus elongatus }}^{b^{*}, c^{*}}$ \\
\hline & & Symbolophorus & $\underline{\text { Symbolophorus veranyi }}^{c^{*}}$ \\
\hline Ophidiiforme & Carapidae & $\underline{\text { Carapus }}$ & $\underline{\text { Carapus acus }}^{\mathrm{a}}$ \\
\hline & Ophidiidae & Benthocometes & $\underline{B e n t h o c o m e t e s ~ r o b u s t u s ~}^{c}$ \\
\hline Osmeriforme & Argentinidae & Argentina & $\underline{\text { Argentina sphyraena }}{ }^{\mathrm{a}, \mathrm{b}, \mathrm{c}}$ \\
\hline Perciforme & Blenniidae & $\underline{\text { Blennius }}$ & $\underline{\text { Blennius ocellaris }}^{\text {a }}$ \\
\hline & Callionymidae & $\underline{\text { Callionymus }}$ & Callionymus lyra ${ }^{b^{*}}$ \\
\hline & & & $\underline{\text { Callionymus maculatus }} \mathrm{a}^{\mathrm{a}^{*}, \mathrm{~b}^{*}}$ \\
\hline & & $\underline{\text { Synchiropus }}$ & $\underline{\text { Synchiropus phaeton }}^{\mathrm{b}, \mathrm{c}}$ \\
\hline & Carangidae & $\underline{\text { Trachurus }}$ & $\underline{\text { Trachurus mediterraneus }}^{\mathrm{a}}$ \\
\hline & & & $\underline{\text { Trachurus picturatus }}^{\mathrm{a}, \mathrm{b}}$ \\
\hline & & & $\underline{\text { Trachurus trachurus }}^{\text {a,b,c }}$ \\
\hline & Centracanthidae & $\underline{\text { Centracanthus }}$ & $\underline{\text { Centracanthus cirrus }}^{\mathrm{a}, \mathrm{c}}$ \\
\hline & & $\underline{\text { Spicara }}$ & $\underline{\text { Spicara maena }}^{\mathrm{a}}$ \\
\hline & & & $\underline{\text { Spicara smaris }}^{\mathrm{a}}$ \\
\hline & Centrolophidae & $\underline{\text { Centrolophus }}$ & $\underline{\text { Centrolophus niger }}^{\mathrm{c}}$ \\
\hline & Cepolidae & Cepola & Cepola macrophthalm \\
\hline
\end{tabular}




\begin{tabular}{|c|c|c|c|}
\hline & Epigonidae & Epigonus & Epigonus constanciae $^{\mathrm{c}^{*}}$ \\
\hline & & & Epigonus denticulatus ${ }^{\mathrm{b}, \mathrm{c}}$ \\
\hline & & & $\underline{\text { Epigonus telescopus }}^{\mathrm{c}}$ \\
\hline & Gobiidae & $\underline{\text { Deltentosteus }}$ & $\underline{\text { Deltentosteus quadrimaculatus }}^{\text {a }}$ \\
\hline & & $\underline{\text { Lesueurigobius }}$ & $\underline{\text { Lesueurigobius friesii }}^{\mathrm{b}}$ \\
\hline & Labridae & Acantholabrus & Acantholabrus palloni $^{\mathrm{b}}$ \\
\hline & & $\underline{\text { Labrus }}$ & $\underline{\text { Labrus viridis }}^{\mathrm{b}^{*}}$ \\
\hline & Mullidae & $\underline{\text { Mullus }}$ & $\underline{\text { Mullus barbatus }}^{\mathrm{a}, \mathrm{b}^{*}}$ \\
\hline & & & $\underline{\text { Mullus surmuletus }}^{\mathrm{a}, \mathrm{b}}$ \\
\hline & Polyprionidae & Polyprion & Polyprion americanus $^{\mathrm{c}^{*}}$ \\
\hline & Serranidae & $\underline{\text { Anthias }}$ & $\underline{\text { Anthias anthias }}{ }^{a}$ \\
\hline & & $\underline{\text { Serranus }}$ & $\underline{\text { Serranus cabrilla }}^{\mathrm{a}}$ \\
\hline & & & $\underline{\text { Serranus hepatus }}^{\mathrm{a}}$ \\
\hline & Sparidae & $\underline{\text { Boops }}$ & $\underline{\text { Boops boops }}^{\mathrm{a}, \mathrm{b}}$ \\
\hline & & $\underline{\text { Dentex }}$ & $\underline{\text { Dentex dentex }}^{\mathrm{a}}$ \\
\hline & & $\underline{\text { Diplodus }}$ & $\underline{\text { Diplodus annularis }}^{\mathrm{a}^{*}}$ \\
\hline & & Pagellus & Pagellus acarne $^{a, b}$ \\
\hline & & & $\underline{\text { Pagellus bogaraveo }}^{\mathrm{a}^{*}, \mathrm{~b}, \mathrm{c}}$ \\
\hline & & & $\underline{\text { Pagellus erythrinus }}{ }^{\mathrm{a}, \mathrm{b}}$ \\
\hline & Trachinidae & $\underline{\text { Trachinus }}$ & $\underline{\text { Trachinus araneus }}^{\mathrm{a}}$ \\
\hline & & & $\underline{\text { Trachinus draco }}{ }^{\mathrm{a}}$ \\
\hline & & & Trachinus radiatus $^{\text {a }}$ \\
\hline & Trachiuridae & $\underline{\text { Lepidopus }}$ & $\underline{\text { Lepidopus caudatus }}^{\mathrm{a}^{*}}$ \\
\hline & Uranoscopidae & $\underline{\text { Uranoscopus }}$ & $\underline{\text { Uranoscopus scaber }}^{a}$ \\
\hline & Zeidae & $\underline{\text { Zeus }}$ & $\underline{\text { Zeus faber }}^{\mathrm{a}, \mathrm{b}}$ \\
\hline Pleuronectiforme & Bothidae & $\underline{\text { Arnoglossus }}$ & $\underline{\text { Arnoglossus imperialis }}{ }^{\text {a }}$ \\
\hline & & & $\underline{\text { Arnoglossus laterna }}^{\mathrm{a}}$ \\
\hline & & & $\underline{\text { Arnoglossus rueppelii }}^{\mathrm{a}}$ \\
\hline & & & $\underline{\text { Arnoglossus thori }}^{\mathrm{a}}$ \\
\hline & Citharidae & $\underline{\text { Citharus }}$ & $\underline{\text { Citharus linguatula }}^{\mathrm{a}^{*}}$ \\
\hline & Cynoglosiidae & $\underline{\text { Symphurus }}$ & Symphurus ligulatus ${ }^{b, c^{*}}$ \\
\hline & & & $\underline{\text { Symphurus nigrescens }}^{\mathrm{b}^{*}}$ \\
\hline
\end{tabular}




\begin{tabular}{|c|c|c|c|}
\hline & Scophthalmidae & $\underline{\text { Lepidorhombus }}$ & $\underline{\text { Lepidorhombus boscii }}{ }^{*, \mathrm{~b}, \mathrm{c}}$ \\
\hline & & & $\underline{\text { Lepidorhombus whiffiagonis }}^{\mathrm{a}^{*}, \mathrm{bc}}$ \\
\hline & & Psetta & $\underline{\text { Psetta maxima }}^{\mathrm{a}^{*}}$ \\
\hline & Soleidae & $\underline{\text { Microchirus }}$ & $\underline{\text { Microchirus variegatus }}^{\mathrm{a}, \mathrm{c}^{*}}$ \\
\hline & & $\underline{\text { Solea }}$ & $\underline{\text { Solea solea }}^{a}$ \\
\hline Scorpaeniforme & Peristediidae & Peristedion & $\underline{\text { Peristedion cataphractum }}^{\mathrm{a}, \mathrm{b}, \mathrm{c}}$ \\
\hline & Scorpaenidae & $\underline{\text { Scorpaena }}$ & $\underline{\text { Scorpaena elongata }} \mathrm{a}^{*, \mathrm{~b}}$ \\
\hline & & & $\underline{\text { Scorpaena loppei }}^{\text {a }}$ \\
\hline & & & $\underline{\text { Scorpaena notata }}^{\mathrm{a}}$ \\
\hline & & & $\underline{\text { Scorpaena porcus }}^{\text {a }}$ \\
\hline & & & $\underline{\text { Scorpaena scrofa }}{ }^{a}$ \\
\hline & Sebastidae & $\underline{\text { Helicolenus }}$ & $\underline{\text { Helicolenus dactylopterus }}$ \\
\hline & & & $\underline{\text { dactylopterus }}^{\mathrm{b}, \mathrm{c}}$ \\
\hline & Triglidae & $\underline{\text { Aspitrigla }}$ & $\underline{\text { Aspitrigla cuculus }}^{\mathrm{a}, \mathrm{b}}$ \\
\hline & & Chelidonichthys & $\underline{\text { Chelidonichthys lastoviza }}^{\text {a }}$ \\
\hline & & & $\underline{\text { Chelidonichthys lucernus }}^{\text {a }}$ \\
\hline & & & Chelidonichthys obscurus $^{\mathrm{a}^{*}}$ \\
\hline & & Eutrigla & $\underline{\text { Eutrigla gurnardus }}^{\mathrm{a}^{*}}$ \\
\hline & & Lepidotrigla & $\underline{\text { Lepidotrigla cavillone }}^{\mathrm{a}, \mathrm{b}^{*}}$ \\
\hline & & & $\underline{\text { Lepidotrigla dieuzeidei }}^{\mathrm{a}, \mathrm{b}}$ \\
\hline & & $\underline{\text { Trigla }}$ & $\underline{\text { Trigla lyra }}^{\mathrm{a}^{*}, \mathrm{~b}, \mathrm{c}}$ \\
\hline Stomiiforme & Gonostomatidae & $\underline{\text { Gonostoma }}$ & $\underline{\text { Gonostoma denudatum }}^{\mathrm{c}^{*}}$ \\
\hline & Sternoptychidae & $\underline{\text { Argyropelecus }}$ & $\underline{\text { Argyropelecus hemigymnus }}^{\mathrm{c}^{*}}$ \\
\hline & Stomiidae & $\underline{\text { Chauliodus }}$ & $\underline{\text { Chauliodus sloani }}^{\mathrm{c}^{*}}$ \\
\hline & & $\underline{\text { Stomias }}$ & $\underline{\text { Stomias boa boa }}{ }^{c}$ \\
\hline & Sternoptychidae & $\underline{\text { Maurolicus }}$ & $\underline{\text { Maurolicus muelleri }}^{\mathrm{b}}$ \\
\hline Syngnathiforme & Centriscidae & Macroramphosus & $\underline{\text { Macroramphosus scolopax }}{ }^{\mathrm{a}, \mathrm{b}}$ \\
\hline Zeiforme & Caproidae & $\underline{\text { Capros }}$ & $\underline{\text { Capros aper }}^{\mathrm{a}, \mathrm{b}, \mathrm{c}}$ \\
\hline yes Carcharhiniforme & Scyliorhinidae & $\underline{\text { Galeus }}$ & $\underline{\text { Galeus melastomus }}^{\mathrm{b}, \mathrm{c}}$ \\
\hline & & $\underline{\text { Scyliorhinus }}$ & $\underline{\text { Scyliorhinus canicula }}^{\mathrm{a}, \mathrm{b}, \mathrm{c}}$ \\
\hline & & & $\underline{\text { Scyliorhinus stellaris }}^{\mathrm{b}^{*}}$ \\
\hline
\end{tabular}




\begin{tabular}{|c|c|c|c|}
\hline & Triakidae & $\underline{\text { Mustelus }}$ & Mustelus mustelus $^{\text {a }}$ \\
\hline Chimaeriforme & Chimaeridae & Chimaera & $\underline{\text { Chimaera monstrosa }} \mathrm{b}^{\mathrm{b}, \mathrm{c}}$ \\
\hline \multirow[t]{9}{*}{ Rajiforme } & Dasyatidae & Dasyatis & $\underline{\text { Dasyatis pastinaca }}^{\mathrm{a}^{*}}$ \\
\hline & Rajidae & Dipturus & $\underline{\text { Dipturus oxyrinchus }}^{\mathrm{b}, \mathrm{c}}$ \\
\hline & & Leucoraja & $\underline{\text { Leucoraja naevus }}^{\mathrm{a}^{*}}$ \\
\hline & & $\underline{\text { Raja }}$ & $\underline{\text { Raja asterias }}^{\text {a }}$ \\
\hline & & & $\underline{\text { Raja brachyura }}{ }^{a, b^{*}}$ \\
\hline & & & $\underline{\text { Raja clavata }}{ }^{a, b, c}$ \\
\hline & & & $\underline{\text { Raja miraletus }}^{\text {a }}$ \\
\hline & & & $\underline{\text { Raja montagui }}$ a,b,c \\
\hline & & & $\underline{\text { Rostroraja alba }}{ }^{\mathrm{c}^{*}}$ \\
\hline \multirow[t]{6}{*}{ Squaliforme } & Centrophoridae & $\underline{\text { Centrophorus }}$ & $\underline{\text { Centrophorus granulosus }}^{c}$ \\
\hline & & & $\underline{\text { Centrophorus uyato }}^{c}$ \\
\hline & Dalatiidae & $\underline{\text { Dalatias }}$ & Dalatias licha $^{c}$ \\
\hline & & Etmopterus & $\underline{\text { Etmopterus spinax }}^{\mathrm{c}}$ \\
\hline & Squalidae & $\underline{\text { Squalus }}$ & $\underline{\text { Squalus acanthias }}^{\mathrm{b}}$ \\
\hline & & & $\underline{\text { Squalus blainville }}^{\mathrm{b}, \mathrm{c}}$ \\
\hline Squatiniforme & Squatinidae & $\underline{\text { Squatina }}$ & $\underline{\text { Squatina squatina }}{ }^{\mathrm{a}^{*}, b^{*}}$ \\
\hline Torpediniforme & Torpedinidae & Torpedo & Torpedo marmorata ${ }^{\mathrm{a}^{*}}$ \\
\hline
\end{tabular}




\section{References}

Anon., 1998. Campagne internationale de chalutage démersal en Méditerranée (MEDITS): manuel des protocoles. Biol. Mar. Medit. 5, 515-572.

Beisel, J.N., Usseglio-Polatera, P., Thomas, S., Moreteau, J.C., 1998. Stream community structure in relation to spatial variation: the influence of mesohabitat characteristics. Hydrobiologia 389, 7388.

Beisel, J.N., Usseglio-Polatera, P., Bachmann, V., Moreteau, J. C., 2003. A comparative analysis of evenness index sensitivity. Int. Rev. Hydrobiol. 88, 3-15.

Berger, W.H., Parker, F. L., 1970. Diversity of planktonic Foraminifera in deep sea sediments. Science 168, 1345-1347.

Bertrand, J.A., Gil de Sola, L., Papaconstantinou, C., Relini, G., Souplet, A., 2002a. The general specifications of the MEDITS surveys. Sci. Mar. 66, 9-17.

Bertrand, J.A., Leonori, I., Dremiere, P.Y., Cosimi, G., 2002b. Depth trajectory and performance of a trawl used for an international bottom trawl survey in the Mediterranean. Sci. Mar. 66, 169-182.

Bianchi, G., 1992. Demersal assemblages of the continental shelf and upper slope of Angola. Mar. Ecol. Prog. Ser. 85, 101-120.

Blanchard, F., 2001. Une approche de la dynamique des peuplements de poissons démersaux exploités: analyse comparée de la diversité spécifique dans le golfe de Gascogne (océan Atlantique) et dans le golfe du Lion (mer Méditerranée). Aquat. Living Resour. 14, 29-40.

Boyle, T.P., Smillie, G.M., Anderson, J.C., Beeson, D.R., 1990. A Sensitivity Analysis of 9 Diversity and 7 Similarity Indexes. Research Journal WPCF 62, 749-762.

Cartes, J.E., Grémare, A., Maynou, F., Villora-Moreno, S., Dinet, A., 2002. Bathymetric changes in the distributions of particulate organic matter and associated fauna along a deep sea transect down the Catalan sea slope (north-western Mediterranean). Prog. Oceanogr. 53, 29-56.

Clarke, K.R., Warwick, R.M., 1998. A taxonomic distinctness index and its statistical properties. J. Appl. Ecol. 35, 523-531. 
Clarke, K.R., Warwick, R.M., 1999. The taxonomic distinctness measure of biodiversity: weighting of step lengths between hierarchical levels. Mar. Ecol. Prog. Ser. 184, 21-29.

Clarke, K.R., Gorley, R.N., 2001. PRIMER v5: User manual (PRIMER- E Ltd, Plymouth, United Kingdom) Plymouth, 91 pp.

Clarke, K.R., Warwick, R.M., 2001. A further biodiversity index applicable to species lists: variation in taxonomic distinctness. Mar. Ecol. Prog. Ser. 216, 265-278.

Colloca, F., Cardinale, M., Belluscio, A., Ardizzone, G.D., 2003. Pattern of distribution and diversity of demersal assemblages in the central Mediterranean sea. Estuar. Coast. Shelf S. 56, 469480.

Fiorentini, L., Dremière, P.Y., Leonori, I., Sala, A., Palumbo, V., 1999. Efficiency of the bottom trawl used for the Mediterranean International Trawl Survey (MEDITS). Aquat. Living Resour. 12, $187-205$.

Fujita, T., Tadashi, I., Ishito, Y., 1995. Depth-gradient structure on the demersal fish community on the continental shelf and slope off Sendai Bay, Japan. Mar. Ecol. Prog. Ser. 118, 13-23.

Gaertner, J.C., Bertrand, J.A., Souplet, A., 2002. STATIS-CoA: A methodological solution to assess the spatio-temporal organization of species assemblages. Application to the demersal assemblages of the French Mediterranean Sea. Sci. Mar. 66, 221-232.

Gaertner, J.C., Bertrand, J., Gil de sola, L., Durbec, J.P., Ferrandis, E., Souplet, A., 2005a. Large spatial scale variation of demersal fish assemblage structure on the continental shelf of the NW mediterranean sea. Mar. Ecol. Prog. Ser. 297, 245-257.

Gaertner, J.C., Bertrand, J., Samanis, D., Souplet, A., 2005b. Spatio-temporal organization patterns of demersal assemblages of the east of Corsica (Mediterranean Sea). Vie et Milieu 55, 81-89.

Gaertner, J.C., Bertrand, J.A., Relini, G., Papaconstantinou, C., Mazouni, N., Gil de Sola, L., Durbec, J.P., Jukic-Peladic, S., Souplet, A., 2007. Spatial pattern in species richness of fish demersal assemblages on the continental shelf of the northern Mediterranean Sea: a multiscale analysis. Mar. Ecol. Prog. Ser. in press.

Gaston, K.J., 1994. Rarity. Chapman and Hall, London, 220 pp. 
Gaston, K.J., and Spicer, V. I., 1998. Biodiversity: an introduction. Blackwell Sci., Oxford, 208 pp. Gooday, A.J., Hughes, J.A., Levin, L.A., 2001. The foraminiferan macrofauna from three North Carolina (USA) slope sites with contrasting carbon flux: a comparison with the metazoan macrofauna. Deep-Sea Res. I 48, 1709-1739.

Gristina, M., Bahri, T., Fiorentino, F., Garofalo, G., 2006. Comparison of demersal fish assemblages in three areas of the Strait of Sicily under different trawling pressure. Fish. Res. 81, $60-71$.

Gutzmann, E., Martinez Arbizu, P., Rose, A., Veit-Köhler, G., 2004. Meiofauna communities along an abyssal depth gradient in the Drake Passage. Deep-Sea Res. I 51, 1617-1628.

Heip, C., 1974. A new index measuring evenness. J. Mar. Biol. Assoc. U.K. 54, 555-557.

Ihaka, R. and Gentleman, R., 1996. R: a language for data analysis and graphics. J.

Comput. Graph. Stat., 5, 299-314.

Joliffe, I.T., 1986. Principal Component Analysis. Springer-Verlag, 271 pp.

Labropoulou, M. and Papaconstantinou, C., 2004. Community structure and diversity of demersal fish assemblages: the role of fishery. Sci. Mar. 68, 215-226.

Magnussen, E., 2002. Demersal fish assemblages of Faroe Bank: species composition, distribution, biomass spectrum and diversity. Mar. Ecol. Prog. Ser. 238, 211-225.

Magurran, A.E., 2004. Measuring biological diversity. Blackwell Sci., Oxford, 260 pp.

Manté, C., Claudet, J., Rebzani-Zahaf, C., 2003. Fairly processing rare and common species in multivariate analysis of ecological series - Application to macrobenthic communities from Algiers harbour. Acta Biotheor. 51, 277-294.

Margalef, R., 1958. Information theory in ecology. Gen. Syst. 3, 36-71.

May, R.M., 1975. Patterns of species abundance and diversity. In M. L. Cody, J. M. Diamond, eds., Ecology and Evolution of Communities, Harvard University Press, 81-120.

Mazouni (ed), 2006. Syscolag: the sharing of knowledge as a basis to implement integrated coastal management. Vie et Milieu, 56, 265-345. 
Mérigot, B., Bertrand, J.A., Mazouni, N., Manté, C., Durbec, J.P., Gaertner, J.C., 2007. A multicomponent analysis of species diversity of groundfish assemblages on the continental shelf of the Gulf of Lions (northwestern Mediterranean Sea). Estuar. Coast. Shelf S., 73, 123-136.

Moranta, J., Stefanescu, C., Massuti, E., Morales-Nin, B., Lloris, D., 1998. Fish community structure and depth-related trends on the continental slope of the Balearic Islands (Algerian basin, western Mediterranean). Mar. Ecol. Prog. Ser. 171, 247-259.

Peet, R.K., 1974. The measurement of species diversity. Ann. Rev. Ecol. Syst. 5, 285-307.

Purvis, A., Hector, A., 2000. Getting the measure of biodiversity. Nature 405, 212-219.

Ramos-Miranda, J., Mouillot, D., Flores Hernandez, D., Sosa Lopez, A., Chi, T.D., Ayala Perez, L., 2005. Changes in four complementary facets of fish diversity in a tropical coastal lagoon after 18 years: a functional interpretation. Mar. Ecol. Prog. Ser. 304, 1-13.

Relini, G., Bertrand, J., Zamboni, A., 1999. Synthesis of the knowledge on Bottom fishery resources in central Mediterranean (Italy and Corsica). Biol. Mar. Medit. 6 (Suppl. 1), 1-868.

Ricotta, C., De Zuliani, E., Pacini, A., Avena, G.C., 2001. On the mutual relatedness of evenness measures. Comm. Ecol. 2, 51-56.

Rogers, S.I., Clarke, K.R., Reynolds, J.D., 1999. The taxonomic distinctness of coastal bottomdwelling fish communities of the North-east Atlantic. J. Anim. Ecol. 68, 769-782.

Rosenzweig, M.L., 1995. Species diversity in space and time. Cambridge University Press, Cambridge, 458 pp.

Shannon, C.E., Weaver, W., 1949. The Mathematical Theory of Communication. University of Illinois, Urbana, Illinois.

Simpson, E.H., 1949. Measurement of diversity. Nature 163, 688.

Smith, B., Wilson, J.B., 1996. A consumer's guide to evenness indices. Oikos 76, 70-82.

Stora, G., Bourcier, M., Arnoux, A., Gerino, M., Le Champion, J., Gilbert, F., Durbec, J.P., 1999. The deep-sea macrobenthos on the continental slope of the north-western Mediterranean Sea: a quantitative approach. Deep-Sea Res. I 46, 1339-1368. 
Thomas, C.D., Mallorie, H.C., 1985. Rarity, species richness and conservation: butterflies of the Atlas Mountains in Morocco. Biol. Conserv. 33, 95-117.

Thurston, M.H., Bett, B.J., Rice, A.L., Jackson, P.A.B., 1994. Variations in the invertebrate abyssal megafauna in the North Atlantic Ocean. Deep-Sea Res. I 41, 1321-1348.

Tilman, D., 1996. Biodiversity: population versus ecosystem stability. Ecology 77, 350-363.

von Euler, F., Svensson, S., 2001. Taxonomic distinctness and species richness as measures of functional structure in bird assemblages. Oecologia 129, 304-311.

Ungaro, N., Marano, C.A., Marsan, R., Martino, M., Marzano, M.C., Strippoli, G., Vlora, A., 1999. Analysis of demersal species assemblages from trawl surveys in the South Adriatic sea. Aquat. Living Resour. 12, 177-185.

Warwick, R.M., Clarke, K.R., 1995. New biodiversity measures reveal a decrease in taxonomic distinctness with increasing stress. Mar. Ecol. Prog. Ser. 129, 301-305.

Warwick, R.M., Clarke, K.R., 1998. Taxonomic distinctness and environmental assessment. J. Anim. Ecol. 35, 532-543.

Wilsey, B.J., Chalcraft, D.R., Bowles, C.M., Willig, M.R., 2005. Relationships among indices suggest that richness is an incomplete surrogate for grassland biodiversity. Ecology 86, 1178-1184. 


\section{Figures}

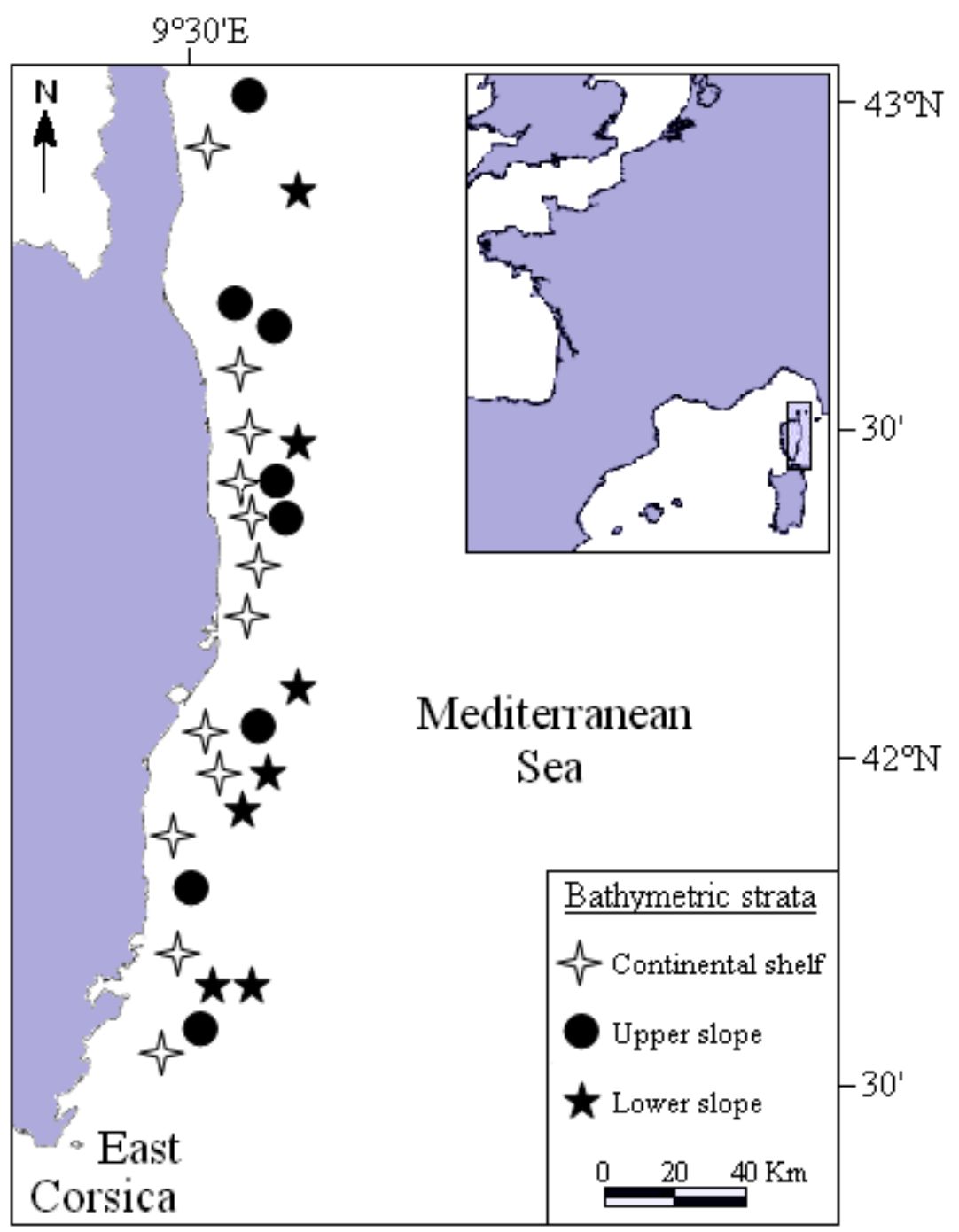

Fig. 1: Map of the study area, showing location of stations. 
a)
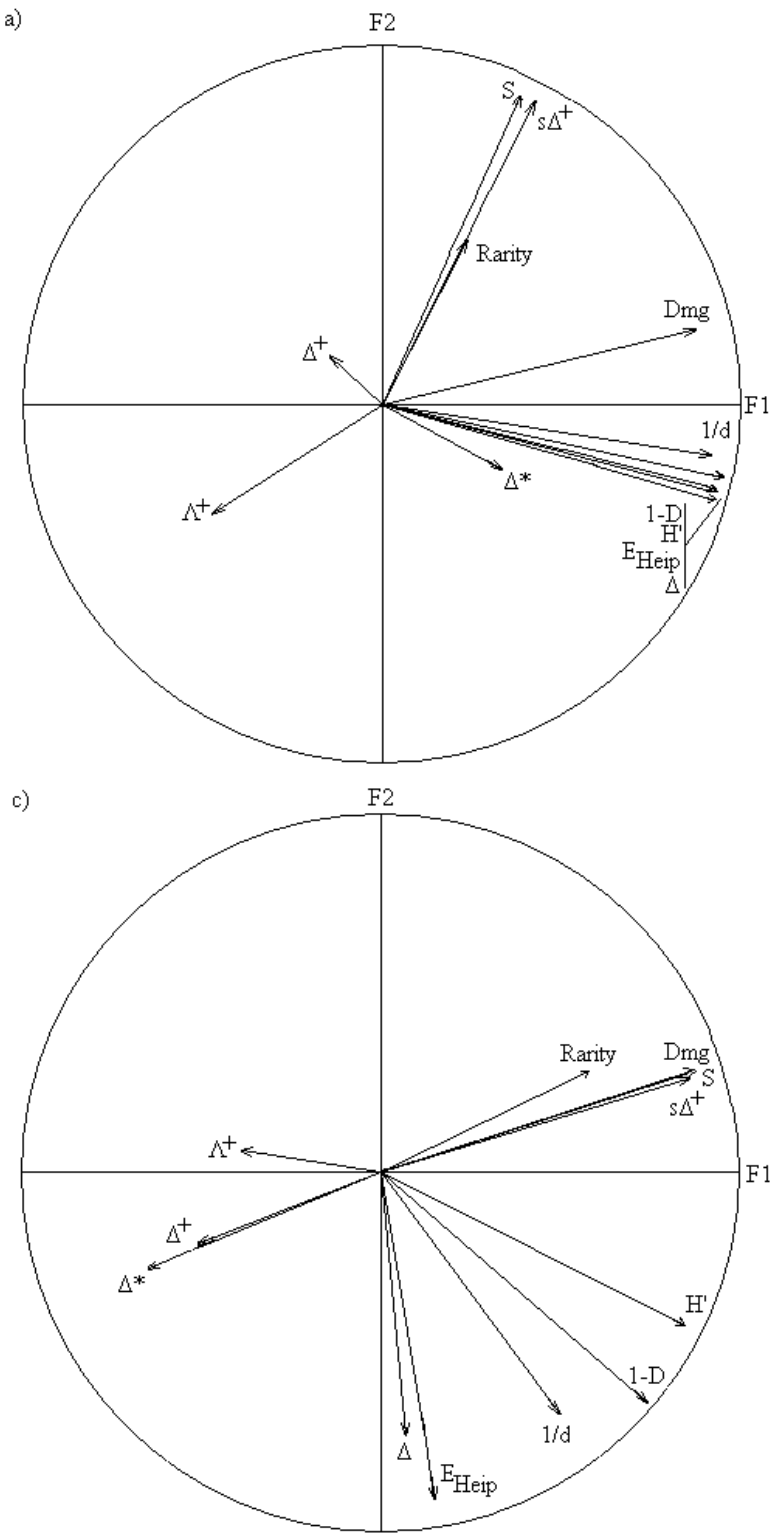

b)

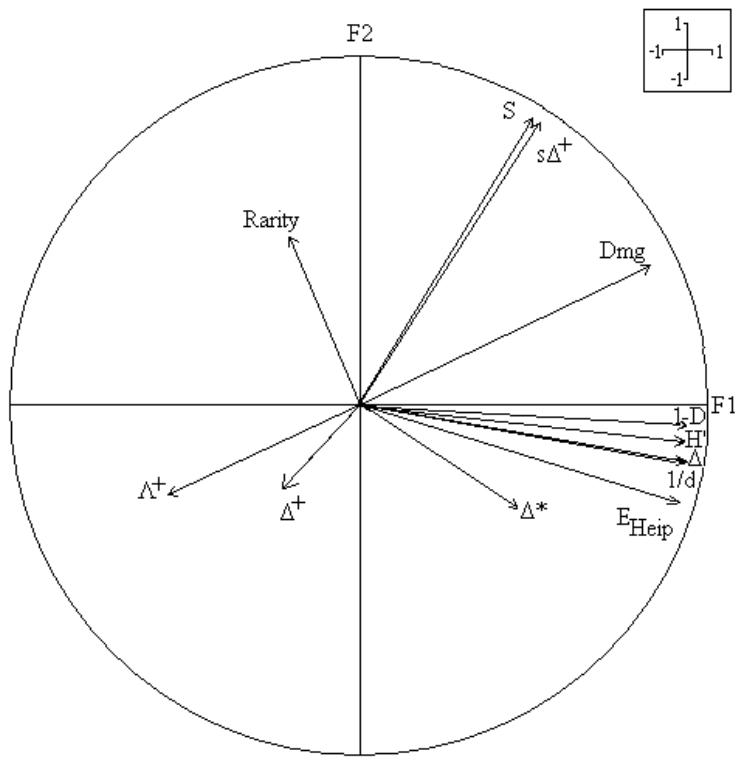

Fig. 2: Correlation circle of the PCA based on rank correlation matrices calculated between 12 species diversity descriptors analysed a) on the continental shelf $(n=38), b)$ on the upper slope $(n=$ 18) and c) on the lower slope $(\mathrm{n}=23)$. 
Table 1: Species diversity components and descriptors studied. $x_{i}(i=1, \ldots, S)$ denotes the abundance of the $i$ th species, $N\left(=\sum_{i} x_{i}\right)$ is the total number of individuals in the sample, $p_{i}\left(=x_{i} / N\right)$ is the proportion of all individuals belonging to species $i, N_{\max }$ is the number of individuals of the most abundant species. $\omega_{i j}$ is the "distinctness weight" given to the path length linking species $i$ to the first common node with species $j$ in the hierarchical classification, the double summations are over all pairs of species $i$ and $j$.

\begin{tabular}{llll}
\hline Component & Descriptor name & Formula & Expected properties \\
\hline $\begin{array}{l}\text { Number } \\
\text { of species }\end{array}$ & Species density & $\begin{array}{l}S=\text { Number } \\
\text { of species by trawl }\end{array}$ & $\begin{array}{l}\text { Standardize species } \\
\text { richness per unit area }\end{array}$
\end{tabular}

\begin{tabular}{lllll} 
& Margalef & $D_{\mathrm{mg}}=\frac{(S-1)}{\ln (N)}$ & $\begin{array}{l}\text { Adjusted species } \\
\text { richness by } N\end{array}$ & Margalef (1958) \\
\hline Rarity & Rarity & $\begin{array}{l}\text { Number of species } \\
\text { with less than } 5 \% \\
\text { of occurrence }\end{array}$ & $\begin{array}{l}\text { Define rarity in term } \\
\text { of species range size }\end{array}$ & Heip (1974) \\
\hline Evenness & Heip & $E_{\text {Heip }}=\frac{\exp \left(H^{\prime}\right)-1}{S-1}$ & $\begin{array}{l}\text { Sensitive to } \\
\text { rare species }\end{array}$ & Sensitive to \\
& Berger Parker & $\frac{1}{d}=\frac{N}{N_{\max }}$ & dominant species & Berger and Parker (1970)
\end{tabular}

$\begin{array}{lllll}\begin{array}{l}\text { Number of } \\ \begin{array}{l}\text { Species }+ \\ \text { evenness }\end{array}\end{array} & \text { Shannon-Wiener } & H^{\prime}=-\sum_{i=1}^{S} p_{i} \log p_{i} & \begin{array}{l}\text { Sensitive to } \\ \text { rare species }\end{array} & \begin{array}{l}\text { Shannon and } \\ \text { Weaver (1949) }\end{array} \\ & \text { Simpson diversity } & 1-D=1-\left(\sum_{i=1}^{S} p_{i}^{2}\right) & \begin{array}{l}\text { Sensitive to } \\ \text { dominant species }\end{array} & \text { Simpson (1949) }\end{array}$

\begin{tabular}{|c|c|c|c|c|}
\hline \multirow[t]{6}{*}{$\begin{array}{l}\text { Species } \\
\text { taxonomy }\end{array}$} & $\begin{array}{l}\text { Taxonomic } \\
\text { diversity }\end{array}$ & $\Delta=2 \frac{\sum \sum_{i<j}^{\left(\omega_{i j} x_{i} x_{j}\right.}}{N(N-1)}$ & $\begin{array}{l}\text { Extension of } 1-D \\
\text { including taxonomic } \\
\text { relatedness }\end{array}$ & Warwick and Clarke (1995) \\
\hline & $\begin{array}{l}\text { Taxonomic } \\
\text { distinctness }\end{array}$ & $\Delta *=\frac{\sum \sum_{i<j}^{\omega_{i j} x_{i} x_{j}}}{\sum \sum_{i<j} x_{i} x_{j}}$ & $\begin{array}{l}\text { Form of } \Delta \text { limiting } \\
\text { the influence of species } \\
\text { dominance, reflecting } \\
\text { pure taxonomic } \\
\text { relatedness }\end{array}$ & Warwick and Clarke (1995) \\
\hline & $\begin{array}{l}\text { Average } \\
\text { taxonomic } \\
\text { distinctness }\end{array}$ & $\Delta^{+}=2 \frac{\sum \sum_{i<j}^{\omega_{i j}}}{S(S-1)}$ & $\begin{array}{l}\text { Equivalent to } \Delta \text { and } \Delta * \\
\text { in presence-absence data }\end{array}$ & Clarke and Warwick (1998) \\
\hline & $\begin{array}{l}\text { Variation in } \\
\text { taxonomic } \\
\text { distinctness }\end{array}$ & $\Lambda^{+}=2 \frac{\sum \sum_{i<j}\left(\omega_{i j}-\bar{\omega}\right)^{2}}{S(S-1)}$ & $\begin{array}{l}\text { Evenness of the taxonomic } \\
\text { level distribution in the } \\
\text { taxonomic tree }\end{array}$ & Clarke and Warwick (2001) \\
\hline & & where $\bar{\sigma}=\Delta^{+}$ & & \\
\hline & $\begin{array}{l}\text { Total taxonomic } \\
\text { distinctness }\end{array}$ & $s \Delta^{+}=\frac{\sum \sum_{i<j}\left(\omega_{i j}\right)}{(S-1)}$ & $\begin{array}{l}\text { Measure of total } \\
\text { taxonomic breadth }\end{array}$ & Clarke and Warwick (2001) \\
\hline
\end{tabular}


Table 2: General characteristics of the surveys 1995-1999 along the east coast of Corsica.

Mean values of diversity indices are indicated with their standard deviation.

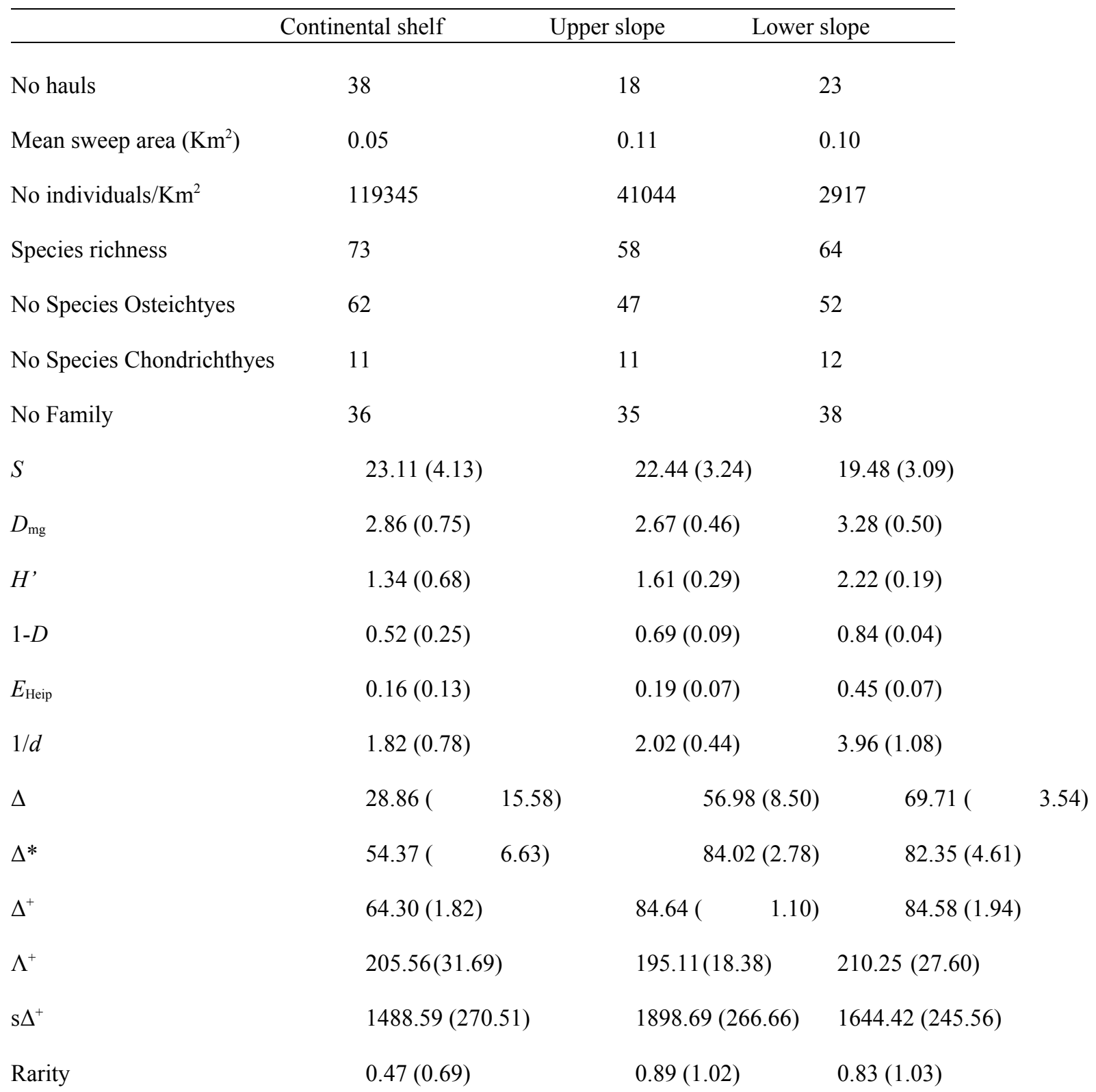


Table 3: Dominance patterns on the continental shelf and the slope.

\begin{tabular}{lcc}
\hline Species & Dominance (\%) & Cumulative dominance (\%) \\
\hline Continental shelf & & 77.47 \\
$\underline{\text { Spicara smaris }}$ & 77.47 & 81.52 \\
$\underline{\text { Mullus barbatus }}$ & 4.05 & 85.18 \\
$\underline{\text { Centracanthus cirrus }}$ & 3.65 & 87.55 \\
$\underline{\text { Trachurus mediterraneus }}$ & 2.37 & 89.64 \\
$\underline{\text { Trachurus trachurus }}$ & 2.09 & 91.32 \\
$\underline{\text { Spicara maena }}$ & 1.68 & 92.52 \\
$\underline{\text { Serranus hepatus }}$ & 1.20 & 93.43 \\
$\underline{\text { Sardina pilchardus }}$ & 0.91 & 94.33 \\
$\underline{\text { Lepidotrigla cavillone }}$ & 0.90 & 94.93 \\
$\underline{\text { Macroramphosus scolopax }}$ & 0.60 &
\end{tabular}

Upper Slope

$\begin{array}{lll}\text { Gadiculus argenteus argenteus } & 35.37 & 35.37\end{array}$

$\begin{array}{lll}\text { Capros aper } & 19.23 & 54.60\end{array}$

$\begin{array}{lll}\text { Chlorophthalmus agassizi } & 12.15 & 66.74\end{array}$

$\begin{array}{lll}\text { Micromesistius poutassou } & 8.33 & 75.08\end{array}$

$\begin{array}{lll}\text { Scyliorhinus canicula } & 4.70 & 79.78\end{array}$

$\begin{array}{lll}\text { Galeus melastomus } & 3.77 & 83.54\end{array}$

$\begin{array}{lll}\text { Argentina sphyraena } & 3.54 & 87.08\end{array}$

$\begin{array}{lll}\text { Lepidotrigla dieuzeidei } & 2.26 & 89.34\end{array}$

$\begin{array}{lll}\text { Aspitrigla cuculus } & 2.14 & 91.48\end{array}$

$\begin{array}{lll}\text { Macroramphosus scolopax } & 1.47 & 92.95\end{array}$

Lower Slope

$\begin{array}{lll}\text { Galeus melastomus } & 20.92 & 20.92\end{array}$

$\begin{array}{lll}\text { Hymenocephalus italicus } & 19.30 & 40.22\end{array}$

$\begin{array}{lll}\text { Caelorinchus caelorhincus } & 9.77 & 49.99\end{array}$

$\begin{array}{lll}\text { Phycis blennoides } & 8.35 & 58.34\end{array}$

$\begin{array}{lll}\text { Nezumia sclerorhynchus } & 7.30 & 65.64\end{array}$ 
dactylopterus

Hoplostethus mediterraneus

mediterraneus

$\begin{array}{lll}\text { Etmopterus spinax } & 4.88 & 82.11 \\ \text { Chlorophthalmus agassizi } & 3.50 & 85.61\end{array}$

Gadiculus argenteus argenteus

2.40

88.01 
Table 4: Spearman rank correlation coefficients calculated between all the species diversity descriptors considered a) on the continental shelf, b) on the upper slope and c) on the lower slope. All correlations are significant with $p<0.05$, except for underlined values. The Spearman coefficient distribution under null hypothesis was approximated by a normal distribution with mean equal to 0 and standard deviation equal to $1 / \sqrt{ }(n-1)$.

a)

\begin{tabular}{lllllllllllll}
\hline & $S$ & $D_{\mathrm{mg}}$ & $H^{\prime}$ & $1-D$ & $E_{\text {Heip }}$ & $1 / d$ & $\Delta$ & $\Delta^{*}$ & $\Delta^{+}$ & $\Lambda^{+}$ & $\mathrm{s} \Delta^{+}$ & Rarity \\
\hline$S$ & 1.00 & & & & & & & & & & & \\
$D_{\mathrm{mg}}$ & 0.53 & 1.00 & & & & & & & & & & \\
$H^{\prime}$ & $\underline{0.23}$ & 0.80 & 1.00 & & & & & & & & & \\
$1-D$ & $\underline{0.21}$ & 0.74 & 0.97 & 1.00 & & & & & & & & \\
$E_{\text {Heip }}$ & $\underline{0.17}$ & 0.78 & 0.96 & 0.93 & 1.00 & & & & & & & \\
$1 / d$ & $\underline{0.24}$ & 0.66 & 0.9 & 0.91 & 0.93 & 1.00 & & & & & & \\
$\Delta$ & $\underline{0.18}$ & 0.78 & 0.97 & 0.97 & 0.94 & 0.90 & 1.00 & & & & & \\
$\Delta^{*}$ & $\underline{0.02}$ & 0.33 & 0.29 & 0.27 & 0.36 & 0.32 & 0.40 & 1.00 & & & & \\
$\Delta^{+}$ & $\underline{-0.06}$ & $\underline{0}$ & $\underline{-0.15}$ & $\underline{-0.16}$ & $\underline{-0.08}$ & $\underline{-0.16}$ & $\underline{-0.08}$ & 0.30 & 1.00 & & & \\
$\Lambda^{+}$ & -0.37 & -0.38 & -0.41 & -0.35 & -0.39 & -0.37 & -0.28 & $\underline{0.25}$ & 0.37 & 1.00 & & \\
$\mathrm{~s} \Delta^{+}$ & 0.97 & 0.52 & $\underline{0.20}$ & $\underline{0.17}$ & $\underline{0.14}$ & $\underline{0.19}$ & $\underline{0.15}$ & $\underline{0.07}$ & $\underline{0.13}$ & -0.30 & 1.00 & \\
$\underline{R}$ Rarity & 0.38 & 0.34 & $\underline{0.11}$ & $\underline{0.10}$ & $\underline{0.07}$ & $\underline{0.07}$ & $\underline{0.15}$ & $\underline{0.23}$ & $\underline{0.11}$ & $\underline{-0.15}$ & 0.38 & 1.00
\end{tabular}

b)

\begin{tabular}{lllllllllllll}
\hline & $S$ & $D_{\mathrm{mg}}$ & $H^{\prime}$ & $1-D$ & $E_{\text {Heip }}$ & $1 / d$ & $\Delta$ & $\Delta^{*}$ & $\Delta^{+}$ & $\Lambda^{+}$ & $\mathrm{s} \Delta^{+}$ & Rarity \\
\hline$S$ & 1.00 & & & & & & & & & & \\
$D_{\mathrm{mg}}$ & 0.82 & 1.00 & & & & & & & & & & \\
$H^{\prime}$ & $\underline{0.18}$ & 0.57 & 1.00 & & & & & & & & & \\
$1-D$ & $\underline{0.12}$ & 0.48 & 0.94 & 1.00 & & & & & & & & \\
$E_{\text {Heip }}$ & $\underline{-0.18}$ & $\underline{0.25}$ & 0.88 & 0.88 & 1.00 & & & & & & & \\
$1 / d$ & $\underline{-0.04}$ & $\underline{0.38}$ & 0.85 & 0.95 & 0.88 & 1.00 & & & & & & \\
$\Delta$ & $\underline{-0.05}$ & $\underline{0.39}$ & 0.93 & 0.93 & 0.92 & 0.89 & 1.00 & & & & & \\
$\Delta^{*}$ & $\underline{-0.27}$ & $\underline{0.10}$ & $\underline{0.39}$ & $\underline{0.33}$ & $\underline{0.39}$ & $\underline{0.33}$ & 0.58 & 1.00 & & & & \\
$\Delta^{+}$ & $\underline{-0.22}$ & -0.48 & $\underline{-0.27}$ & $\underline{-0.29}$ & $\underline{-0.20}$ & $\underline{-0.34}$ & $\underline{-0.26}$ & $\underline{-0.09}$ & 1.00 & & & \\
$\Lambda^{+}$ & $\underline{0.03}$ & $\underline{-0.02}$ & -0.48 & -0.52 & $\underline{-0.56}$ & -0.49 & $\underline{-0.37}$ & $\underline{0.33}$ & $\underline{0.09}$ & 1.00 & & \\
$\mathrm{~s} \Delta^{+}$ & 1.00 & 0.81 & $\underline{0.17}$ & $\underline{0.10}$ & $\underline{-0.20}$ & $\underline{-0.06}$ & $\underline{-0.06}$ & $\underline{-0.25}$ & $\underline{-0.21}$ & $\underline{0.04}$ & 1.00 & \\
$\underline{R a r i t y}$ & $\underline{0.16}$ & $\underline{-0.06}$ & $\underline{-0.17}$ & $\underline{-0.21}$ & $\underline{-0.15}$ & $\underline{-0.19}$ & $\underline{-0.18}$ & $\underline{-0.51}$ & $\underline{-0.28}$ & $\underline{0.18}$ & $\underline{-0.06}$ & 1.00
\end{tabular}


c)

\begin{tabular}{lllllllllllll}
\hline & $S$ & $D_{\mathrm{mg}}$ & $H^{\prime}$ & $1-D$ & $E_{\text {Heip }}$ & $1 / d$ & $\Delta$ & $\Delta^{*}$ & $\Delta^{+}$ & $\Lambda^{+}$ & $\mathrm{s} \Delta^{+}$ & Rarity \\
\hline$S$ & 1.00 & & & & & & & & & & & \\
$D_{\mathrm{mg}}$ & 0.90 & 1.00 & & & & & & & & & & \\
$H^{\prime}$ & 0.66 & 0.66 & 1.00 & & & & & & & & & \\
$1-D$ & 0.48 & 0.44 & 0.94 & 1.00 & & & & & & & & \\
$E_{\text {Heip }}$ & $\underline{-0.18}$ & $\underline{-0.08}$ & 0.51 & 0.69 & 1.00 & & & & & & & \\
$1 / d$ & $\underline{0.23}$ & $\underline{0.12}$ & 0.67 & 0.81 & 0.65 & 1.00 & & & & & & \\
$\Delta$ & $\underline{-0.07}$ & $\underline{-0.05}$ & 0.36 & 0.48 & 0.58 & $\underline{0.32}$ & 1.00 & & & & & \\
$\Delta^{*}$ & -0.58 & -0.48 & -0.43 & $\underline{-0.35}$ & $\underline{0.07}$ & -0.39 & 0.56 & 1.00 & & & & \\
$\Delta^{+}$ & -0.53 & $\underline{-0.27}$ & $\underline{-0.35}$ & $\underline{-0.29}$ & $\underline{0.17}$ & $\underline{-0.17}$ & $\underline{0.11}$ & 0.47 & 1.00 & & & \\
$\Lambda^{+}$ & $\underline{-0.20}$ & $\underline{-0.29}$ & $\underline{-0.25}$ & $\underline{-0.27}$ & $\underline{-0.17}$ & $\underline{-0.08}$ & $\underline{-0.21}$ & $\underline{0.15}$ & $\underline{0.11}$ & 1.00 & & \\
$\mathrm{~s} \Delta^{+}$ & 0.98 & 0.92 & 0.65 & 0.47 & $\underline{-0.17}$ & $\underline{0.23}$ & $\underline{-0.11}$ & -0.57 & -0.40 & $\underline{-0.19}$ & 1.00 & \\
$\underline{R a r i t y}$ & 0.55 & 0.56 & $\underline{0.26}$ & $\underline{0.17}$ & $\underline{-0.18}$ & $\underline{0.08}$ & $\underline{-0.01}$ & $\underline{-0.27}$ & $\underline{-0.15}$ & -0.53 & 0.56 & 1.00
\end{tabular}

